The Polish Journal of the Arts and Culture. New Series 10

(2/2019): 109-132 [ARTYKUE]

DOI: $10.4467 / 24506249$ PJ.19.014.11986

\title{
„Chłopcy nie mają się dobrze”. Porady różowej brygady, Ameryka i toksyczna męskość
}

\author{
Monika RAwsKA
}

\begin{abstract}
Streszczenie
Artykuł poświęcony jest nowej, ośmioodcinkowej edycji programu Porady różowej brygady (Queer Eye, 2018-) udostępnionego na platformie Netflix, ujętej w kontekście dyskusji dotyczącej toksycznej męskości i masowych morderstw w amerykańskich liceach.

Optymistyczne opinie dotyczące programu Porady różowej bryga$d y$ koncentrują się zwykle na wymiarze tolerancji wobec mniejszości seksualnych lub - jak chcą tego sami prowadzący - akceptacji. Zwracając uwagę na wymiar gatunkowy (ustalona i powtarzalna dramaturgia odcinków), ideologiczny (figura homoseksualnego eksperta) i ideologiczno-produkcyjny (dobór bohaterów programu), przeanalizuję wizerunki uczestników, wskazując na odstępstwa od dominujących stereotypowych wzorców męskości, które wydają się reprezentować poszczególne postacie, upatrując w tym działaniu, jeśli nie rozszerzenia kategorii męskości, to przynajmniej drobnych rys na jej monolicie.
\end{abstract}

Słowa kluczowe: Kultura popularna, Queer Eye, Telewizja, Makeover show, Toksyczna męskość

Monika RawsKa kulturoznawczyni i filmoznawczyni, graficzka, doktorantka w Katedrze Kulturoznawstwa Uniwersytetu SWPS. Publikowała na łamach „Panoptikum”, „Dialogu” i „małej kultury współczesnej”. W kręgu jej zainteresowań badawczych znajdują się kultura popularna, nowe kino gatunków oraz filmowe reprezentacje przestrzeni miejskich.

https://orcid.org/oooo-0oo3-4310-8452

E-MAIL:mjrawska@gmail.com 
Artykuł powstał na podstawie wystąpienia (pod tym samym tytułem) na II Interdyscyplinarnej Konferencji Doktorantów i Młodych Naukowców: „Dawny i obecny wizerunek mężczyzny w perspektywie XXI wieku”, która odbyła się 7-8 czerwca 2018 roku na Wydziale Humanistycznym Uniwersytetu Warmińsko-Mazurskiego w Olsztynie. Tytuł „Chłopcy nie mają się dobrze” odwołuje się do tytułu felietonu Michaela Iana Blacka The Boys Are Not All Right (Black 2018).

\section{Wprowadzenie}

14 lutego 2018 roku w Parkland na Florydzie, w Douglas High School, doszło do strzelaniny - zginęło siedemnaście osób i tyle samo zostało rannych. Wydarzenie wstrząsnęło Stanami Zjednoczonymi (jak wyliczyła pozarządowa organizacja Gun Violence Archive, badająca podobne przypadki, był to już osiemnasty atak od początku trwającego ledwie półtora miesiąca roku) i zyskało szerokie komentarze w mediach, w których zwracano uwagę, że sprawcami w masowych strzelaninach (zjawisko ma w USA swoją nazwę mass shootings) są wyłącznie chłopcy i mężczyźni ${ }^{1}$, w przeważającej większości biali. Próby usensownienia tych wydarzeń ogniskują się na ogół wokół kategorii toksycznej męskości (Wright 2018), będącej nie tylko przedmiotem analiz badaczy i badaczek, ale również pojęciem funkcjonującym i szeroko wykorzystywanym w dyskursie publicznym (czasem nawet w formie poręcznego hasła). Odwołuje się do niego również Michael Ian Black, aktor i komik, w felietonie opublikowanym w „The New York Times”, podkreślając, jak szkodliwe jest dorastanie $\mathrm{z}$ tak represywnymi wzorcami:

Nawet niezatajanie własnego strachu staje się równoznaczne z degradacją; nie mamy przecież żadnego wzorca męskości pozwalającego na bojaźń, smutek, bycie delikatnym i przeżywanie gorszego dnia, choć zdarza się to każdemu z nas. [...] Musi być jakiś sposób, by poszerzyć znaczenie bycia mężczyzną bez utraty naszej męskości. (Black 2018)

Black nie jest oczywiście odosobniony w swoich spostrzeżeniach i postulatach. Wzmożona za sprawą szkolnych strzelanin ekspozycja kwestii męskości, sytuowanej jako problem do rozwiązania, zbiegła się z wznowieniem

1 Istotność tego faktu podkreślał kulturoznawca i edukator Jackson Katz w filmie Maska twardziela. Przemoc, media i kryzys męskości (1999, reż. Sut Jhally), zwracając jednocześnie uwagę, że był on zupełnie pomijany przez ówczesnych publicystów. 
makeoverowego programu Porady różowej brygady² (pierwowzór stacji Bravo: Queer Eye for the Straight Guy [2003-2007]), w którym piątka ekspertów-homoseksualistów ${ }^{3}$ remontuje domy oraz uczy, jak się ubierać, gotować i przyjmować gości. Nowa wersja, wyprodukowana przez platformę streamingową Netflix, spotkała się z bardzo dobrym przyjęciem. Publicyści entuzjastycznie zauważali, że program jest bardzo potrzebny, ponieważ celebruje środowiska queerowe oraz pokazuje heteroseksualnym mężczyznom, że nie muszą wstydzić się swoich emocji, mogą o nich rozmawiać, wzajemnie się wspierać oraz w ten sposób budować i pielęgnować męską przyjaźn (Baragona 2018). Garrett Schlichte, nie bez przesadnego optymizmu, nazwał go nawet „antidotum na kulturę toksycznej męskości” (Schlichte 2018).

\section{Wściekli biali mężczyźni}

Socjolog Michael Kimmel, autor licznych publikacji poświęconych kategorii męskości oraz powiązanej z nią agresji, zauważał w książce Angry white men. American masculinity at the end of an era:

„Wrogami” białego amerykańskiego mężczyzny nie są tak naprawdę kobiety ani mężczyźni innych ras. Naszym wrogiem jest ideologia męskości, którą odziedziczyliśmy po naszych ojcach, a oni po swoich ojcach, ideologia obiecująca bezprecedensową siłę nabywczą z tragicznie zubożałą inteligencją emocjonalną. Zaakceptowaliśmy ideologię męskości, która zostawia nas z poczuciem pustki i osamotnienia, kiedy skutecznie ją realizujemy, jeszcze gorzej, kiedy czujemy, że realizujemy ją nieskutecznie. (Kimmel 2013, 21)

Badacz proponuje również termin „nieodżałowany przywilej”4 (aggrieved entitlement), na określenie przekonania, podświadomie podzielanego przez białych mężczyzn z klasy średniej, którym przygląda się w swoich analizach. Zwraca uwagę na funkcję archetypu self-made mana oraz amerykańskiego snu, stanowiących podstawę wciąż żywych wyobrażeń o USA jako ziemi obiecanej, gdzie dzięki ciężkiej pracy oraz przyzwoitości zawsze w końcu osiągnie się sukces. Rzeczywistość jest jednak dużo bardziej skomplikowana

2 Jeden z sezonów pierwszej wersji programu emitowany był w 2009 roku przez stację TVN Style. Stąd też - wydawałoby się nieco infantylizujący - tytuł polskiej dystrybucji.

${ }^{3}$ Jeden z ekspertów, Karamo Brown, sam jest zresztą absolwentem Douglas High School.

4 Wojciech Śmieja, w tłumaczeniu wywiadu z Kimmelem, proponuje „zawiedzione poczucie uprzywilejowania" (Kimmel 2019, 7). 
i zawód, wynikający ze zderzenia z realiami, staje się jednym z fundamentów przekonania o krzywdzie i niesprawiedliwości oraz źródłem bolesnego poczucia porażki. To z tych uczuć rodzi się potrzeba gloryfikacji przeszłości, prowadząca do chęci przywrócenia dawnego porządku, mamiąca możliwością odtworzenia raju, być może wcale nie utraconego. Co ciekawe, te zaburzenia percepcji kierują wściekłość zazwyczaj w stronę jednostek i grup znajdujących się jeszcze niżej na drabinie społecznej. Za podsumowanie takiej postawy niech posłuży zdanie Czarna kobieta ukradta mi pracę, będące tytułem odcinka talk show, którego gośćmi byli trzej biali mężczyźni przekonani o dyskryminacji w miejscu pracy oraz, występujący w charakterze komentatora, Kimmel, przytaczający tę anegdotę we wprowadzeniu do książki. Badacz, przywołując wiele analogicznych przykładów, mogących wydawać się bardziej lub mniej zabawnymi opowieściami, zwraca jednak uwagę na realne zagrożenie wynikające $\mathrm{z}$ takich przekonań:

Nieodżałowany przywilej usprawiedliwia zemstę wobec tych, którzy wyrządzili ci krzywdę; to rekompensata za poniżenie. Poniżenie to kastracja: poniż kogoś, a odbierzesz mu męskość. Dla wielu mężczyzn poniżenie musi być pomszczone, inaczej przestają czuć się mężczyznami. (Kimmel 2013, 96)

Black swoją refleksję przywołał ponownie 18 maja 2019 roku, kiedy w Santa Fe High School w Teksasie doszło do kolejnego masowego morderstwa - zginęło dziesięć osób, a trzynaście zostało rannych. Według danych z Gun Violence America między wydarzeniami z Portland i Santa Fe miało miejsce 6o podobnych wypadków. Statystyki są nieubłagane, a uwzględnione w nich liczby zatrważają, zwłaszcza że w efekcie strzelaniny w Parkland uczniowie szkoły zainicjowali młodzieżowy ruch Never Again i zorganizowali marsz March for Our Lives, w którym miliony młodych ludzi żądało podjęcia przez władze stanowczych kroków i zakończenia przemocy wynikającej z dostępności broni (Witt 2018; March for Our Lives, b.d).

Kimmel poświęca masowym morderstwom oraz szkolnym strzelaninom znaczną część książki. Wskazuje na negatywny wpływ tzw. kultury jocków, czyli chłopaków, którzy, wedle stereotypu, nie są przesadnie inteligentni, ale odnoszą sukcesy w sportach zespołowych, zapewniając szkołom dodatkowe środki, i nadużywają swojej pozycji szkolnych celebrytów (zachowując się w sposób agresywny wobec tych mniej popularnych/usportowionych). Są oni zresztą często wprost obwiniani przez samych sprawców masakr. Badacz zauważa: 
Praktycznie każdy ze strzelców opisywał swoje szkolne dni jako nieustające rzucanie wyzwań poprzez zastraszanie, szczucie epitetami sugerującymi homoseksualizm, przemoc fizyczną, prześladowanie, aż w końcu coś w nich „pękało”. Ci chłopcy spędzali dużą część dnia, próbując zatrzymać ciągły potok krytyki ich męskości. Desperacko próbowali dowieść krytykom, że się mylą, dokonać zemsty na dręczycielach i tych dzieciakach, które się śmiały, lub też szli im na rękę, nie odzywali się i pozwalali na to. Psychiatra James Gilligan w swojej wnikliwej książce sugeruje, że przemoc ma swoje źródła w „strachu przed wstydem i szyderstwem, w przytłaczającym pragnieniu, by uniemożliwić innym śmianie się, sprawiając, że zamiast tego będą szlochać”. (Kimmel 2013, 98-99)

Powołując się na analizy Katherine Newman oraz jej zespołu z University of Massachusetts, badacz wylicza pięć czynników, które przyczyniają się do szkolnych strzelanin:

1. Marginalizacja społeczna (nieustające zastraszanie i sugerowanie homoseksualności [gay baiting]);

2. Indywidualne predyspozycje (psychologiczna kategoria-wytrych - powód dla którego niektórzy marginalizowani chłopcy atakują, a pozostali wypracowują inne strategie radzenia sobie);

3. Scenariusze kulturowe (jakieś medium, które zainspirowało lub usprawiedliwiło ich działanie $)^{5}$;

4. Porażka systemu nadzoru (zarówno fizycznego, jak i psychicznego; strzelcy umknęli uwadze tych, którzy mogli dostrzec znaki ostrzegawcze);

5. Dostępność broni.

5 Takimi scenariuszami stają się poprzednie przypadki przemocy, zwłaszcza ten w Columbine High School (2o kwietnia 1999), w którym zginęło piętnaście osób i dwadzieścia cztery zostały ranne. W niektórych środowiskach sprawcy, Eric Harris i Dylan Klebold, otaczani są swoistym kultem. Warto również dodać, że Columbine stanowi znaczącą cezurę - mówi się o masakrach sprzed i po niej. Te po są bardziej „polityczne”, skupione na atakowaniu kultury jocków. „Columbine stało się jedynym scenariuszem, z którego czerpią niemalże wszyscy strzelcy" (Kimmel 2013, 98). Przywoływany już Jackson Katz zwracał uwagę, że agresywna męskość jest normą kulturową konstruowaną przez media. W sekcji filmu poświęconej szkolnym strzelaninom, odwołując się również do Harrisa i Kleboda, wskazywał na konieczność zmiany paradygmatu. Również Patrycja Włodek w artykule Hipermęskość: skala kryzysu zauważa, że w amerykańskiej kulturze audiowizualnej „zależność przemocy i męskości była przyjmowana jako oczywista i niekwestionowana”, zwracając przy tym uwagę, iż „zarówno funduje [ona - M.R] wyobrażenie o »prawdziwej« męskości, jak i leży u podstaw jej kryzysu" (Włodek 2020, 33). 
Podkreślenia wymaga konieczność współwystępowania wszystkich tych czynników, by doszło do ataku szału (rampage) (Kimmel 2013, 99).

Występująca w prasie komentującej wydarzenia z amerykańskich szkół kategoria toksycznej męskości stała się swoistym kluczem, choć właściwie nie sposób dojść, kto jest autorem tego terminu. Osadzić można go jednak w kontekście stworzonego przez Rolanda F. Levanta, psychologa, wieloletniego redaktora naczelnego czasopisma „Psychology of Men and Masculinity”, i jego współpracowników inwentarza norm dotyczącego męskich ról, definiującego ideologię tradycyjnej męskości w następujących siedmiu wymiarach:

wymóg unikania wszystkiego, co kobiece; nakaz ograniczania życia emocjonalnego; nacisk na twardość i agresję; nakaz bycia samodzielnym; nacisk na osiągnięcie statusu ponad wszystko; nierelacyjność; uprzedmiatawiające podejście do seksualności; lęk i nienawiść w stosunku do homoseksualistów. (Levant 1996, 261)

Ideologia tradycyjnej męskości - uznanej w 2019 roku przez American Psychological Association za „szkodliwą i socjalizującą chłopców do tłumienia emocji” (Pappas 2019) - stanowi więc podglebie dla kategorii toksycznej męskości, którą psychiatra Terry A. Krupers definiuje jako „konstelację społecznie regresywnych męskich cech, służących pielęgnowaniu dominacji, dewaluacji kobiet, homofobii i bezcelowej przemocy. Toksyczna męskość wiąże się silnie z takimi męskimi skłonnościami, które prowadzą do oporu w psychoterapii” (Krupers 2004, 714) .

\section{Kryzys męskości?}

Toksyczna męskość właściwie zdetronizowała popularną dotąd w dyskursie publicznym kategorię kryzysu męskości rozumianego ,jako zagubienie mężczyzn wśród wielości konkurujących ze sobą wzorów męskości oraz przejściowych trendów kreowanych przez media i marketing” (Wyrwińska 2020,6). Dorota Wyrwińska w swoich badaniach, niejako wbrew podsycanym przez media oczekiwaniom (spodziewała się „opowieści mężczyzn o ich

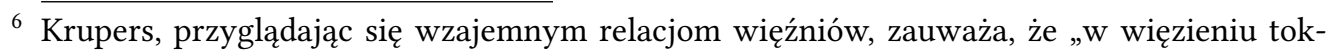
syczna męskość jest przejaskrawiona. Wybucha w bójkach na spacerniaku, napaściach na oficerów, w ohydnym zjawisku gwałtów więziennych i innych hiperrywalizacyjnych, czasem agresywnych, interakcjach” (Krupers 2004, 714). 
zagubieniu, sposobach odnajdywania się w różnorodności wzorów męskości czy też o strategiach kształtowania własnej męskiej tożsamości” (Wyrwińska 2020, 4)), zauważyła, że choć mężczyźni

mówili o różnych dotykających ich problemach (przykładowo, o rosnących oczekiwaniach partnerek i dzieci, o presji nakładanej na nich przez coraz trudniejszą sytuację na rynku pracy, o lęku przed bezrobociem), [...] w żadnym wypadku, także wśród młodszych mężczyzn, nie było widać jakichkolwiek przejawów tożsamościowego zagubienia. (Wyrwińska 2020, 4-5)

Socjolożka przygląda się historycznym przemianom męskości (odwołując się między innymi do prac Zbyszka Melosika), wskazując na jej podatność na przeobrażenia. Zauważa mianowicie, że

W przeszłości kulturowe wyznaczniki męskości i kobiecości były w przeważającej mierze determinowane przez społeczną pozycję jednostki, dlatego też, pomimo różnorodności istniejących męskich wzorów (np. dżentelmen, self-mademan, dandys), mężczyźni mieli ograniczony wybór pomiędzy nimi. (Wyrwińska 2020, 106)

Tymczasem, wraz z ponowoczesnością, sztywne struktury uległy „upłynnieniu”, a indywidualizm i refleksyjność stały się kluczowymi wartościami kształtującymi krytyczną postawę wobec kulturowych wzorców płci. Doprowadziło to również do renegocjacji i zmian w układzie relacji między kobietami i mężczyznami (Wyrwińska 2020, 106-107).

Analizując dyskurs prasowy, badaczka stwierdza, że

kwestia płci została wprzęgnięta $\mathrm{w}$ refleksyjny proces, reprezentowany przez wielość głosów i koncepcji przedstawiających zupełnie odrębne wizje męskości, kobiecości oraz kształtu pożądanych relacji między płciami. (Wyrwińska 2020, 106-107)

Niezależnie od przyjętego przez autorów dyskursu (Wyrwińska wyodrębnia cztery najbardziej widoczne: „różnicy”, terapeutyczny, feministyczny i konserwatywny), we wszystkich analizach przejawia się - typowa dla kultury indywidualizmu - indywidualizacja postaw i zachowań oraz istotność nurtu eksperckiego (eksperci to głównie psychoterapeuci i psycholodzy).

Kryzys męskości może się zatem objawiać w postaci niedojrzałości mężczyzn (dyskurs „różnicy”), nieprzepracowanych wewnętrznych napięć i dylematów (dyskurs terapeutyczny), oporu wobec zaakceptowania przemian 
w układzie relacji pomiędzy płciami (dyskurs feministyczny) lub odejścia od realizowania jedynego właściwego wzorca męskości (dyskurs konserwatywny) (Wyrwińska 2020, 107).

Niezależnie jednak od diagnozy źródeł kryzysu „proponowane rozwiązania odnoszą się przeważnie do poziomu jednostkowych działań”, a męskość staje się zadaniem do wykonania, wymagającym „odpowiedniego przygotowania oraz specjalistycznych umiejętności”, „problemem do rozwiązania [...], z którym każdy mężczyzna musi poradzić sobie sam" (choć nie bez wsparcia ekspertów) (Wyrwińska 2020, 107). Badaczka zauważa przy tym, że w dyskusji biorą udział głównie „kobiety, eksperci lub moraliści”, z pominięciem „zwykłych” mężczyzn, co powoduje, że „trudno ocenić, w jaki sposób kryzys męskości jest przez nich doświadczany, kogo dotyczy, w jakich sytuacjach się przejawia oraz - co być może najważniejsze - czy zdaniem mężczyzn w ogóle istnieje" (Wyrwińska 2020, 108). Prowadzi to do wniosku, iż jest to w efekcie kategoria „przezroczysta”, nabierająca „znaczenia dopiero w kontekście narracji, w ramach której jest wykorzystywana”, zazwyczaj przybierająca formę zbioru negatywnych obserwacji, a nie empirycznie podbudowanej diagnozy. „W rezultacie - konkluduje Wyrwińska - kategoria kryzysu męskości nie tylko nie wyjaśnia współczesnej sytuacji mężczyzn, lecz także dodatkowo ją zaciemnia” (Wyrwińska 2020, 108), a dotycząca jej debata więcej mówi „o aktualnym oraz pożądanym układzie relacji między płciami, o pozycji mężczyzn i kobiet w tym układzie, a także o tym, czym w ogóle jest płeć oraz jaką rolę powinna odgrywać w życiu jednostki” (Wyrwińska 2020, 102). Analizy socjolożki, zwłaszcza gdy przygląda się polemice między dyskursem feministycznym a konserwatywnym, są zbieżne z refleksją Krzysztofa Arcimowicza, socjologa kultury z Uniwersytetu w Białymstoku, również wskazującego na normatywny wymiar dostępnych wzorców:

Patriarchalna i nowoczesna wizja męskości toczą walkę o status „prawdy”. Jednak w rzeczywistości niewielu mężczyzn realizuje w swoim życiu wszystkie nakazy zawarte w paradygmacie tradycyjnym. Stosunkowo niewielką grupę stanowią również mężczyźni opowiadający się za wszystkimi postulatami nowoczesnej wizji męskości. Zdecydowana większość mężczyzn we współczesnych społeczeństwach Zachodu realizuje w swoim życiu wartości i wzory zachowań stanowiące kontaminację elementów pochodzących z patriarchalnej i nowoczesnej wizji męskości, przy czym nasilenie cech tradycyjnych i charakterystycznych dla nowego modelu może być różne z przewagą jednej bądź drugiej opcji. (Arcimowicz 2015, 28) 
Badacz również krytycznie odnosi się do dyskursywnie konstruowanej kategorii kryzysu męskości i skłonny jest użyć jej jedynie w kontekście konkretnego modelu, a mianowicie patriarchalnego. Przychyla się bardziej do określenia „przemiany męskości”, które postrzega zresztą jako społecznie korzystne, zwracając uwagę, że to model tradycyjny przysparza mężczyznom więcej problemów (Arcimowicz 2015, 36). Podobnie Wojciech Śmieja, literaturoznawca z Uniwersytetu Śląskiego, zwracając uwagę na widoczne współcześnie „załamanie pewnych genderowych habitusów”, wskazuje, że „sytuacja kryzysowa jest w kategorię męskości wpisana”, a samo pojęcie ma „charakter publicystyczny” (Śmieja 2019, 4). Wszyscy przywołani badacze sugerują zatem, że bardziej uprawnione jest mówienie o męskościach aniżeli męskości ${ }^{7}$.

\section{Wiedza na wynos}

Makeover shows, poświęcone - zazwyczaj spektakularnym - metamorfozom, to wielki sukces kanałów lifestyle'owych, u swoich początków skupionych na poradach w takich obszarach, jak dom i ogród oraz kulinaria. Role doradców i prezenterów przyjmowali w nich nie tylko eksperci, ale również zwykli ludzie, dzielący się swoimi pomysłami i rozwiązaniami (Hill 2008, 143). Annette Hill, medioznawczyni z Uniwersytetu w Lund, zwraca uwagę, że programy lifestyle'owe dzielą się zazwyczaj na dwa typy: instruktarze oraz makeovery, których szczególna popularność rozpoczęła się w latach dziewięćdziesiątych. Te drugie skupiają się na jednostce lub grupie podejmującej się projektu - czy to związanego z domem, czy ze sposobem ubierania się. Badaczka przywołuje opinię jednego z producentów, nazywającego je telewizją „na wynos” (takeout) - widzowie mogą z nich wynieść coś dla siebie: „porady dotyczące wystroju wnętrz, mody, związków, rodzicielstwa i tak dalej” (Hill 2008, 145). Transformacja ma jednak dotyczyć czegoś więcej niż samego wizerunku - sugeruje się, że prawdziwym celem działań jest przemiana wewnętrzna oraz samodoskonalenie (Hill 2008, 143). Badaczka zauważa również ambiwalencję tych formatów: $\mathrm{z}$ jednej strony (za Frances Bonner) mają one wymiar emancypacyjny, bo zwykli ludzie mogą zostać

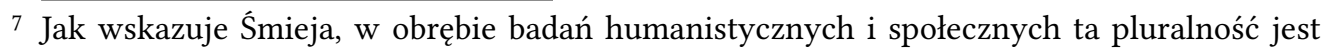
podkreślana i „pojawiła się w literaturze wraz ze słynną książką australijskiej socjolożki Raewyn W. Connell zatytułowaną właśnie Masculinities [wydaną w 1995 roku - M.R.]” (Śmieja 2019, 5). 
dostrzeżeni i wysłuchani, z drugiej jednak istotnym elementem jest krytyka: widzowie, przyjmując perspektywę eksperta ordynującego konkretne zmiany, mogą swobodnie krytykować wybory bohaterów, porównywać się z nimi („przynajmniej ja taki/taka nie jestem”) (Hill 20o8, 143-144, 145).

Socjolożka Ewa Popiel-Rzucidło w artykule Telewizyjne metamorfozy a kultura ryzyka. Socjologiczny portret uczestniczek makeover show zauważa:

Istotą makeover show jest radykalna przemiana wizerunku zwykłych ludzi, przeciętnych widzów, którzy otrzymali wielką szansę i pomoc ze strony „medialnych ekspertów”. Podkreślany do znudzenia schemat before\&after opiera się głównie na emfazie odnoszonej do ekstremalności różnic w życiu bohaterów przed i po metamorfozie, dramatyzmu sytuacji uczestnika poszukującego pomocy i euforii po jej uzyskaniu. (Popiel-Rzucidło 2015, 85)

Analizując wizerunki uczestniczek programów kreowane przez producentów, badaczka tworzy pola semantyczne pięciu kluczowych kategorii: ekspertów, metamorfoz, motywacji oraz uczestniczki przed i po. Szczególnie istotne wydają się zwłaszcza metamorfoza - „zmiana w życiu, psychiczna przemiana, zmiana nastawienia do życia, spełnienie marzeń i nadziei, szansa na zaczęcie życia od nowa, krzyk kobiet, wołanie o akceptację, zmaganie z własnymi słabościami, bólem, samotnością, narodziny piękna, wizualna przemiana” - oraz motywacje: „wyjątkowa, niepowtarzalna szansa, okazja, ostatnia deska ratunku, odwaga, gotowość do zmian” (Popiel-Rzucidło 2015,89 ). Autorka przeprowadziła wywiady z kilkoma uczestniczkami programów, z których wynikało, że istotna była dla nich „chęć oderwania się od wizerunku wykreowanego przez producentów telewizyjnych i przedstawienie faktycznych motywacji, dążeń, oczekiwań, a przede wszystkim roli, jaką metamorfoza pełniła w ich narracjach tożsamościowych" (Popiel-Rzucidło 2015, 92). Ujawnia to rozbieżność między przekazem medialnym a faktycznymi motywacjami oraz manipulację rzeczywistością dla celów programu rozrywkowego. Wyliczone przez badaczkę elementy pól semantycznych tworzą właściwie zamknięty zbiór, co dodatkowo świadczy o schematyczności, widocznej zwłaszcza na poziomie narracji. Struktura programów jest stała i powtarza się, niezależnie od tytułu i przedmiotu metamorfozy. Wynika to ze skuteczności w oddziaływaniu na emocje widzów, co jest naczelnym celem telewizyjnej rozrywki i co prowadzi czasem do sytuacji kuriozalnych, w których cała grupa uczestników jest straumatyzowana przykrymi doświadczeniami, wpływającymi na wszystkie sfery ich życia ${ }^{8}$.

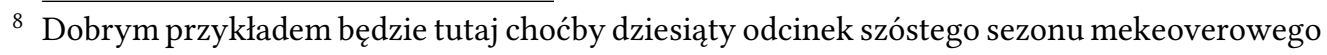


Schemat odcinków w następujący sposób opisuje profesorka Indiana University Bloomington, Brenda R. Weber, w artykule What Makes the Man? Television Makeovers, Made-Over Masculinity, and Male Body Image, analizującym transformacje mężczyzn w programach zdominowanych przez bohaterki:

Program zaczyna się od wstępnego zawstydzania „brzydkiego”, jeszcze nieprzerobionego uczestnika, następnie przechodzi się do obserwacyjnego nadzoru ze strony członków widowni i ekspertów, włącza się możliwość zwierzenia, w trakcie którego bohater mówi o swoim wstydzie i braku pewności siebie, wyciąga się deklaracje o całkowitym oddaniu się w ręce autorytetów, wykonuje się rzeczywistą „pracę” - transformację (praca jest głównie wykonywana przez chirurgów i ekspertów od stylu), a podsumowuje obowiązkowym „szokiem i przerażeniem” ujawnienia, włącznie z euforią nowego-i-udoskonalonego uczestnika i usatysfakcjonowanych ekspertów. (Weber 2006, 293-294)

Autorka celowo nie bierze pod uwagę Porad różowej brygady (oryginalnej serii), ponieważ trzy wybrane przez nią tytuły (Jak się nie ubierać, 10 Years Younger i Extreme Makeover) wyraźniej unaoczniają kontrasty między bohaterami płci żeńskiej i męskiej (Weber 2006, 289). Weber zauważa tkwiącą w samym centrum takich programów ambiwalencję (określa ją wręcz mianem „zagadki”), wynikającą już z faktu, że sam gatunek jest uznawany za kobiecy. „Męskość jest konstruowana jako naturalna” w przeciwieństwie do kobiecości - emocjonalnej ${ }^{9}$ i samozwrotnej, a zatem projektowanej, wymagającej refleksyjności oraz aktywnego działania w stawaniu się (czy też stwarzaniu) kobietą ${ }^{10}$. Opisany powyżej schemat fabularny - wraz

programu stacji TVN Style Afera fryzjera (2015-), w którym znany stylista fryzur (sezony 1-3 - Maciej Wróblewski; sezony 4-8 - Maciej Maniewski) pomaga podupadającym salonom fryzjerskim. W odcinku zarówno szefowa, jak i jej pracownice zostały doświadczone przez los. Właścicielka jest samotną matką w trudnej relacji z dwójką dzieci, fryzjerka Basia wcześnie straciła mamę i wychowywała się w rodzinie zastępczej, a stażystka Paulina została potrącona przez samochód, wskutek czego doświadczyła ciężkich obrażeń głowy (straciła wzrok w jednym oku). Dramatyzm tych wyznań podkreślają oczywiście środki wyrazowe, głównie nachalna muzyka ilustracyjna (informująca widza, że ma do czynienia z przygnębiającymi zwierzeniami), zbliżenia na twarze: zapłakanych kobiet i zatroskanego prowadzącego oraz lagodny komentarz narratora.

9 Jedyną akceptowaną „męską” emocją jest gniew (Weber 2006, 294).

${ }^{10}$ Weber zauważa, że w analizowanych programach ten wysiłek jest bardzo dosłowny, a wiąże się $\mathrm{z}$,»rzeźbieniem « ciała tak, by wyraźniej reprezentowało oznaki kobiecości: duży biust, figurę klepsydry, zadarty nos etc." (Weber 2006, 288). 
z koncentracją na emocjach i bólu psychicznym oraz konieczną otwartością bohaterów na pomoc z zewnątrz - wydaje się przeczyć tradycyjnie rozumianej męskości. Jak jednak zauważa badaczka, celem makeoverów nie jest konstruowanie męskości (ponieważ ta ,jest zawsze obecna jako naturalna dywidenda męskiego ciała”), a raczej „uczynienie jej bardziej rzucającą się w oczy" (Weber 2006, 294). W przypadku bohaterów kluczowy okazuje się specyficznie pojmowany konflikt (oczywiście leżący u podstaw każdej fabuły) - chodzi mianowicie o fakt poświęcania większej części czasu ekranowego żywiołowemu opieraniu się ekspertom. Opór ma znamionować siłę, pewność siebie i nieposłuszeństwo, przeciwstawione słabości, za którą mógłby być uznany udział w programie. Jednocześnie jest on techniką wykorzystywaną przez samo opowiadanie, by „potwierdzić męską dominację nad ulegającym przekształceniom podmiotem” (Weber 2006, 294, 296). Badaczka wskazuje jednak na interesującą prawidłowość: opór ma miejsce jedynie w przypadku, gdy rady pochodzą od kogoś wykraczającego poza tradycyjnie pojmowaną męskość - zatem ekspertki oraz nie-białych ekspertów i/lub takich, których sposób bycia stereotypowo przypisywany jest homoseksualistom w tych sytuacjach to bohater zajmuje pozycję władzy. Tymczasem, gdy rady pochodzą od „heteroseksualnych”, białych mężczyzn („zwykle chirurgów”) „ani mężczyźni, ani kobiety nie stawiają oporu” (Weber 2006, 296). „Usytuowanie homoseksualnego mężczyzny w pozycji autorytetu nie rozmontowuje bezwzględnie heteronormatywnych celów przemiany", ani w przypadku Porad różowej brygady, ani też w analizowanych przez Weber programach, nawet w jednym z odcinków Extreme Makeover, którego bohater ma długoletniego partnera (Weber 2006, 296). Zdaniem autorki, pomimo wyraźnej ambiwalencji (program - niczym instytucja totalna, taka jak wojsko - zmusza do poddania się istniejącym regułom, również - paradoksalnie - tym dotyczącym płci), „makeover służy jako fundament pod nowy typ męskości umożliwiający mężczyźnie deklarowanie konwencjonalnego modelu męskości, jednocześnie domagając się, by wykształcił krytyczną świadomość własnego ciała i dobrego samopoczucia” (Weber 2006, 304). Jak zauważa: „złożoność makeoverów ujawnia podstawową sprzeczność napięć w samym centrum męskości” (Weber 2006, 304):

Męskość po transformacji (made-over) [...] wskazuje, że konflikt i kontestacja są częścią ciągłego (prze)konstruowania płci kulturowej. W zamian makeovery, z całym swoim pozornym podkreślaniem próżności i wizerunku, proponują znaczącą rekontekstualizację tego, jak mężczyzna może być jednocześnie konwencjonalnie męski i bardziej świadomie zaangażowany we własne zdrowie emocjonalne i psychiczne. (Weber 2006, 304-305) 


\section{5 „Brzydkiego nie upiększysz”}

Nowa wersja Porad różowej brygady pojawiła się na platformie Netflix 7 lutego 2018 roku, błyskawicznie zaskarbiając sobie sympatię widzów ${ }^{11}$. Twórcy i eksperci programu zwracali uwagę na zmianę nazwy (nie oddaje tego oczywiście polski tytuł, identyczny z tym z 2009 roku, co, być może, zupełnie niezamierzenie, niesie ze sobą pewien komunikat) - for the Straight Guy ${ }^{12}$ zniknęło, zostało samo Queer Eye ${ }^{13}$, nie ograniczając spektrum (potencjalnych) uczestników jedynie do heteroseksualnych mężczyzn ${ }^{14}$. W wywiadzie dla BUILD Series członkowie nowej Fab5 (bo tak nazwany jest zespół prowadzących) podkreślali, że powrót programu nie jest przypadkowy - w kraju pod rządami republikanów, podsycających sztuczne podziały i antagonizmy,

${ }^{11}$ Drugi sezon miał premierę już 15 czerwca tego samego roku. 21 czerwca na kanale YouTube platformy Netflix zaprezentowano również odcinek specjalny Yass, Australia!. Dwa kolejne sezony pojawiły się w 2019 roku: trzeci 15 marca (akcja przenosi się do Missouri i Kansas), czwarty 19 czerwca. Premiera piątego miała miejsce 5 czerwca 2020. 1 listopada 2019 roku pojawiły się również cztery odcinki specjalne rozgrywające się w Japonii (Queer Eye: We're in fapan!) funkcjonujące na platformie jako osobny program. Prowadzący wydali wspólną książkę Queer Eye. Love Yourself. Love Your Life, która błyskawicznie stała się bestsellerem Amazona (zob. Chan 2018) a sam program otrzymał siedem nagród Emmy. Czterech ekspertów (z wyjątkiem Bobby'ego) wydało własne książki: Tan i Jonathan memuary, Antoni książkę kucharską, Karamo książkę dla dzieci (we współpracy z Jasonem „Rachel” Brownem).

${ }^{12}$ Dla heteroseksualisty.

${ }^{13}$ Queerowym okiem. W języku angielskim have an eye for oznacza bycie spostrzegawczym oraz, podobnie jak w polskim „mieć dobre oko”, co sugeruje pewien poziom estetycznego wyrafinowania.

${ }^{14} \mathrm{~W}$ drugim sezonie bohaterką pierwszego odcinka (Boże, błogosław gejów [God Bless Gay]) jest kobieta, a piątego (Wszystko jest możliwe [Sky's the Limit]) Skyler, transseksualny mężczyzna. W trzecim sezonie kobiety są bohaterkami pierwszego (Od towczyni do bogini [From Hunter to Huntee]), trzeciego (Przysmaki sióstr fones [fones Bar-B-Q]), piątego (Czarna magia [Black Girl Magic]; Jess jest lesbijką). W czwartym sezonie w odcinkach pierwszym (Bez zbędnych ceregieli [Without Further Ado]; to również jedyny odcinek, którego akcja rozgrywa się w Illinois; bohaterką jest Kathi, była nauczycielka muzyki Jonathana), czwartym (Wanda tapie rytm [How Wanda Got Her Groove Back]), szóstym (Opowieść o dwóch kulturach [A Tale of Two Cultures]; Deanna ma meksykańskie korzenie). W czwartym sezonie uczestnikiem jest również osoba z niepełnosprawnością (sparaliżowany Wesley w Niepetnosprawni nie do końca [Disabled but Not Really]). Zwłaszcza w przypadku Jess i Wesleya warto zwrócić uwagę na podwójne wykluczenie - wynikające z nienormatywnej cielesności, orientacji seksualnej oraz przynależności etnicznej. W Queer Eye: We're In Fapan kobiety są bohaterkami odcinka pierwszego (Japońskie wakacje [Japanese Holiday]) i trzeciego (Idealna kobieta [The Ideal Woman]). W trzecim (Crazy in Love) Fab5 pomagają homoseksualnemu Kanowi. 
otwartość na dyskusję oraz zgoda są szczególnie ważne. O ile pierwsze Pora$d y \ldots$ walczyły o tolerancję, reboot chce walczyć o akceptację. Co interesujące, Fab5 odżegnują się od interpretacji swojej pozycji eksperckiej w kluczu stereotypów:

nie jesteśmy grupą gejów, która mówi: „hej, wiemy lepiej, jak się ubierać, układać włosy, dekorować wnętrza, bo jesteśmy gejami”. Nie. Jesteśmy po prostu piątką facetów, która zebrała się, żeby sprawić, że ktoś stanie się lepszy. Nie dlatego, bo jesteśmy gejami, ale ponieważ jesteśmy ekspertami w swoich dziedzinach. (BUILD Series, 2018)

Niezależnie jednak od tych deklaracji, orientacja seksualna prowadzących stanowi element odróżniający program od innych mu podobnych oraz pokrywa się, czy wręcz wykorzystuje, wizerunek funkcjonujący i dobrze ugruntowany w kulturze popularnej. To zresztą nie jedyny sposób wykorzystywania klisz - drugi, który będzie przedmiotem tej analizy, wydaje się bardziej przewrotny, choć równie niesubtelny.

Pierwszy ${ }^{15}$ sezon realizowany był w Georgii, południowym, „,zerwonym stanie” (sympatyzującym z partią republikańską), w czasie wojny secesyjnej należącym do Konfederacji. Żywy jest wciąż wizerunek amerykańskiego głębokiego Południa jako katolickiego, rasistowskiego, niezbyt postępowego oraz zamieszkanego głównie przez „rednecków”16 i „prostaków” (hillbillies) ${ }^{17}$. Bohaterowie inauguracyjnego sezonu, który można potraktować jako swoisty manifest założeń twórców, zostali dobrani i przedstawieni w taki sposób, by rozmontowywać opatrzone stereotypy dotyczące zarówno Południa, jak

\footnotetext{
${ }^{15}$ Akcja drugiego sezonu również rozgrywa się w Georgii.

${ }^{16}$ Obraźliwe określenie używane wobec białych Amerykanów zamieszkujących wiejskie obszary południowych stanów. Stereotyp (oraz kulturowy archetyp) dobrze rozpoznany i wielokrotnie reprodukowany, wiążący się z takimi cechami jak „braki w uzębieniu, kazirodztwo, prostactwo, przemoc i kompletna GŁUPOTA" (Goad 1998, 15). Wywodzi się od fizjologicznej cechy, a mianowicie czerwonej opalenizny. Jak ironicznie zauważa Jim Goad: „przypuszczam, że piekący ból spalonej słońcem kaukaskiej szyi symbolizuje skłonność do nieracjonalnego gniewu, »bycia czerwonym z wściekłości« (seeing red)” (Goad 1998, 83).

${ }^{17}$ Określenie bliskie znaczeniowo „redneckowi”, odnoszące się konkretnie do mieszkańców obszarów wyżynnych (tradycyjnie wyżyny Ozark i Appalachów). Pierwszy raz w druku pojawiło się w „New York Journal” 23 kwietnia 1900 roku i zostało następująco zdefiniowane: „Hill-Billy to wolny i nieskrępowany biały obywatel Alabamy, który mieszka w górach, nie ma nic do powiedzenia, ubiera się, jak może, mówi, jak mu się podoba, pije whiskey, gdy tylko jakąś dostanie i strzela ze swojego rewolweru, ilekroć ma na to ochotę" (Goad 1998, 82). Warto zaznaczyć, że określenia te są przejawem dyskryminacji klasowej.
} 
i męskości. W każdym odcinku Fab $5^{18}$ w składzie: Antoni Porowski (gotowanie), Tan France (moda), Karamo Brown (przedmiotem ekspertyzy ma być kultura, choć jego rola sprowadza się głównie do coachingu), Bobby Berk (wnętrza) i Jonathan Van Ness (pielęgnacja) odwiedzają inną miejscowość, spędzają kilka dni z uczestnikiem (zwykle trzy, cztery) i pomagają mu zadbać o wygląd, samopoczucie oraz relacje z innymi, żywienie i dom.

Uczestnikiem pierwszego odcinka, zatytułowanego Brzydkiego nie upiększysz (You Can't Fix Ugly), jest 57-letni, brodaty Tom Jackson. Widzowi nie zostaje ujawniony jego zawód, kluczowa jest jednak samoidentyfikacja określa się mianem „rednecka”. Metamorfozę chce przejść między innymi dla Abby, swojej byłej żony, którą wciąż kocha. Bohater jest szczery, otwarty, często okazuje wzruszenie i przytula członków Bajecznej Piątki, co w oczywisty sposób zaprzecza stereotypowi. W drugim odcinku Yeti w nowej odstonie (Saving Sasquatch) przemianę przechodzi 36-letni Neil Readdy, inżynier i geek ${ }^{19}$ hinduskiego pochodzenia - jest wycofany i nie wykazuje entuzjazmu. To zresztą jedyny bohater początkowo opierający się ekspertom (ucieka przed nimi w ekspozycji). Dzięki przemianie otwiera się i szczerze okazuje wdzięczność Piątce. Widz zostaje skonfrontowany z kolejnym dobrze ugruntowanym w amerykańskiej kulturze stereotypem geeka wiązanym z toksyczną męskością przez ścisłą hierarchiczność rządzącą grupą oraz przez heteronormatywność i seksizm (Salter i Blodgett 2017). W Zmianie stylu (Dega Don't) bohaterem jest 36-letni Cory Waldrop, policjant (były żołnierz Marines), ojciec rodziny, wielbiciel wyścigów NASCAR oraz wyborca Donalda Trumpa. Cory chce zacząć bardziej starać się dla żony i nie kryje wzruszenia,

${ }^{18}$ Grupa jest zróżnicowana narodowościowo i etnicznie: Tan jest Anglikiem pakistańskiego pochodzenia, Karamo Afroamerykaninem, Antoni Kanadyjczykiem polskiego pochodzenia, to też jedyny ekspert, którego narodowość nie zostaje sproblematyzowana i wykorzystana w celu budowania swoistej wspólnoty doświadczeń, co oczywiście nie powinno szczególnie dziwić.

${ }^{19}$ Jeszcze na początku XX wieku określenie to stosowano w kontekście ludzi z widocznymi uszkodzeniami i dysfunkcjami ciała (synonimicznie wobec terminów: freak, crip) (Wieczorkiewicz 2013, loc. 4357). We współczesnym rozumieniu geek to osoba zainteresowana jakimś tematem (medium lub techniką) bardziej niż interakcjami społecznymi, oddany fan lub fanka jakiegoś uniwersum. Zwłaszcza w kulturze amerykańskiej jest to dobrze rozpoznawalny archetyp z charakterystycznym typem bohatera zaludniającego światy przedstawione filmów młodzieżowych (najczęściej będącego ofiarą wyśmiewania przez jocków). Anastasia Salter i Bridget Blodgett zwracają uwagę, że elementem utrwalonym jako kształtujący tożsamość geeka jest marginalizacja, pomimo tego, że kultura geekowska stała się mainstreamowa (Salter i Blodgett 2017). 
gdy o tym mówi. W rozmowie z Karamo (sprawiającej wrażenie cokolwiek wymuszonej) ubolewa nad złymi relacjami Afroamerykanów i policjantów, zbudowanymi na wzajemnych uprzedzeniach i niechęci. Remedium to komunikacja i szacunek ${ }^{20}$. Anthony „AJ” Brown z fako gej czy nie gej? (To Gay or Not Too Gay), inżynier budownictwa, ma 32 lata. To jedyny uczestnik pierwszego sezonu, który jest homoseksualistą (i pierwszym z dwóch czarnoskórych). Nie przywiązuje specjalnej wagi do ubioru i podkreśla, że nie chce wyglądać „zbyt gejowsko”. 48-letni Bobby Camp z odcinka Twarde zasady (Camp Rules) ma szóstkę dzieci i dwa etaty, by zapewnić byt rodzinie. W tym wypadku kluczowa jest jednak jego religijność i oddanie Kościołowi (działa również jako wolontariusz). W rozmowie z Bobbym, ekspertem od dekoracji wnętrz, pojawia się oczywiście temat wiary i wykluczania osób nieheteronormatywnych. Remedium stanowi komunikacja i szacunek, „Bóg bowiem kocha wszystkich”. 27-letni Remington „Remy” Porter (drugi z czarnoskórych uczestników) z szóstego odcinka, zatytułowanego Człowiek renesansu (The Renaissance of Remington), jest wielbicielem siłowni i chciałby założyć swoją firmę, by pójść w ślady niedawno zmarłego ojca-przedsiębiorcy oraz by móc stać się głową rodziny. 33-letni Joe w Mocno przeciętnym foem (Below Average foe) to mieszkający z rodzicami geek i początkujący stand-uper. Natomiast bohaterem finałowego odcinka, Jak bracia (Hose Before Bros), jest 37-letni Jeremy Holmes, strażak i ojciec piątki adoptowanych dzieci, który prosi, by zamiast domu Fab5 wyremontowali remizę i pomogli w przygotowaniach do corocznej zbiórki pieniędzy.

Już pobieżne przywołanie kluczowych dla fabuł wątków ujawnia celowość doboru bohaterów reprezentujących grupy społeczne i zawodowe zwykle zdominowane przez mężczyzn - tak zwane grupy i instytucje homospołeczne ${ }^{21}-\mathrm{i} /$ lub postrzegane jako zamknięte na inność. Taki wizerunek zostaje rozmontowany poprzez serdeczność w przyjęciu ekspertów

${ }^{20}$ Komunikacja w kontekście kultury indywidualizmu i „kultury przedsiębiorczości” stała się zresztą fetyszem. Jak zauważa Małgorzata Jacyno: „Kult komunikacji miał być odpowiedzią na kult hierarchicznych i sformalizowanych stosunków w instytucjach biurokratycznych. [...] Właściwa komunikacja w związku, podobnie jak w firmie, ma przywracać mu »zdrowie«, poprawiać wydajność i tworzyć warunki samorealizacji. Płynna komunikacja tworzy ponadto atmosferę »kooperacji« $\mathrm{i} »$ komfortu psychicznego «" (Jacyno 2007, 227).

${ }^{21}$ Termin spopularyzowany przez Eve Kosofsky Sedgwick w wydanej w 1985 roku książce Between Men. English Literature and Male Homosocial Desire. Relacje homospołeczne są zarezerwowane dla heteroseksualnych mężczyzn - wyłączają kobiety oraz nieheteronormatywnych mężczyzn. Armia, policja i straż pożarna to przykłady takich instytucji. 
do swoich domów, szczerość w wyrażaniu wdzięczności za wykonaną przez nich pracę, jak również fakt, że wszyscy uczestnicy posiadający rodzinę chcą być lepszymi ojcami i mężami. Nie sposób jednoznacznie ocenić, na ile wylewność bohaterów jest ich osobniczą cechą, a na ile została sprowokowana przez produkcję, czy też jest bezpośrednią reakcją na pełne entuzjazmu zachowanie Piątki. Warto w tym miejscu podkreślić, że programy reality bynajmniej nie chwytają życia na gorąco, a „fabrykowanie dramaturgii” jest w nich częstym zjawiskiem (wbrew realizmowi zawartemu w samej nazwie tego paradygmatu telewizji (Hunt 2017)). Jednocześnie, jak wskazywała Weber, kwestia heteroseksualności (przypodobania się kobietom, widoczna np. w takich wypowiedziach prowadzących: „Czy nie wolałbyś, by to wnętrze było bardziej zachęcające dla pań?”, „Jak będziesz się tak ubierał, nikt nie będzie chciał z tobą pójść do łóżka”, również nieheteroseksualny AJ nie chce wyglądać zbyt „gejowsko”) oraz męskości pozostaje kluczowa - Fab5 albo uczą uczestników, jak być „prawdziwym mężczyzną”, albo umacniają ich w tej roli. Mężczyzna musi być głową rodziny, powinien: mieć w szafie trzy pary dżinsów (granatowe, czarne i sprane) oraz ubierać się adekwatnie do okazji, dbać o rodzinę oraz podejmować wysiłek dbania o siebie, by podobać się partnerce, mieć hobby i ekspercką wiedzę na dany temat (np. w odcinku szóstym Karamo zabiera Remy’ego do destylarni lokalnej szkockiej, by bohater zapoznał się z historią tego alkoholu i procesami powstawania, ponieważ - jak ujął to Brown -„Wiedza co i dlaczego się pije, rozwija cię jako mężczyznę"). Przy tym jednak, dzięki przemianom, otoczenie będzie mogło zobaczyć bohaterów takimi, jakimi są naprawdę, a uczestnicy pogodzą się z trudnymi emocjami i doświadczeniami (głównie straty kogoś bliskiego najczęściej ojca). W kontrze do programów, w których przeważnie występują kobiety, metamorfozy wyglądu nigdy nie są drastyczne - Tan i Jonathan dbają o to, by bohaterowie mogli samodzielnie wykonać zabiegi pielęgnacyjne (doboru dokonują na podstawie czasu, jaki mężczyzna może poświęcić dla siebie), a ubrania są bliskie upodobaniom lub stylowi uczestnika (w tym miejscu szczególnie wyraźnie ujawnia się różnica między innymi programami makeoverowymi, których uczestniczkami są zwykle kobiety). Zespół ekspertów pełni także funkcję cheerleaderów, wychwalających uczestników i zapewniających im dobre samopoczucie przez cały czas metamorfozy, podkreślając również fakt zasługiwania na przemianę (i na dobre rzeczy w ogóle) - element zawstydzania, kluczowy dla makeoverów, jest zatem zminimalizowany, a jeśli występuje, to zazwyczaj w żartobliwej formie. 
Schemat odcinków, trwających średnio trzy kwadranse, jest właściwie identyczny i można podzielić go na cztery części:

1. Wprowadzenie. Ekspozycja bohatera w formie nagrania oglądanego przez Fab5 w drodze na miejsce oraz ustalenie celu metamorfozy. Piątka wpada do domu danego mężczyzny, przegląda jego rzeczy oraz robi bałagan.

2. Nauki. Początek tej sekcji prezentuje impresyjne ujęcia Fab5 w ich lof$\mathrm{cie}^{22}$, planujących metamorfozę. Bohater wraz z jednym (lub więcej) z ekspertów podróżują do miejsca zadania bojowego, mającego pomóc w przemianie i przygotować do osiągnięcia celu metamorfozy oraz pozytywnie wzmocnić uczestnika (np. próbny występ z materiałem komediowym Joego). W drodze powrotnej dochodzi do „rozmowy edukacyjnej” między uczestnikiem a ekspertem/ekspertami, problematyzującej potencjalne zderzenie reprezentowanych przez bohatera wartości z tym, co reprezentuje sobą Brygada (np. przywoływana powyżej rozmowa między Corym a Karamo) - edukującej nawet nie tyle samego uczestnika, co raczej widownię, że nie należy oceniać innych, warto komunikować się ze sobą oraz dawać szanse nawet tym, z którymi potencjalnie niewiele nas łączy.

3. Przed i po. Zaprezentowana zostaje przemiana domu bohatera oraz dostaje on ostatnie lekcje i porady dotyczące pielęgnacji i gotowania (przygotowanie prostej potrawy). Uczestnik prezentuje się Bajecznej Piątce w nowych stylizacjach. Część ta kończy się szczerymi, pełnymi sympatii i ciepła podziękowaniami bohatera oraz życzeniami dla niego. Zarówno uczestnik, jak i Brygada, nie ukrywają wzruszenia.

4. Sprawdzian. Ważne wydarzenie, do którego był przygotowywany uczestnik. Bohater przyrządza posiłek dla bliskich i przyjaciół, którzy po raz pierwszy widzą go (oraz jego dom) po przemianie. Fab5 oglądają i komentują nagranie z finałowego zadania w swoim lofcie. Odcinek zostaje podsumowany bezpośrednimi wypowiedziami poszczególnych członków Brygady, bohatera i jego bliskich do kamery. Część kończy się (zazwyczaj dowcipną) poradą członka/członków Piątki skierowaną do widzów.

By zdynamizować odcinki, metamorfozy trwające kilka dni (często bardzo pracochłonne, zwłaszcza w przypadku remontów) zostają sprowadzone

${ }^{22}$ W Atlancie w pierwszych dwóch sezonach, w Kansas City w trzecim i czwartym. 
do krótkich sekwencji, co powoduje wrażenie pospieszności ${ }^{23}$, kontrastujące z bardziej statycznymi i dłuższymi scenami poważnych rozmów - generuje to również sztuczność, szczególnie wyraźną na tle spontanicznych zachowań i reakcji (zwłaszcza ekspertów). Efekt poszatkowania jest dodatkowo spotęgowany dużą liczbą śródtytułów oraz przebitek (w formie oddzielających krótkie segmenty akcji sekwencji, przedstawiających poszczególnych prowadzących), a także szybkim, dynamicznym montażem. W kadrowaniu preferowane są zbliżenia twarzy wraz ze skupieniem na widocznych reakcjach emocjonalnych. Podglądactwo to oczywiście element bazowy programów reality (Godzic 2004, 100-107), jednak wrażenie naruszania prywatności ujawnia się czasem z całą mocą - zwłaszcza w odcinku czwartym, w którym AJ wyznaje swojej macosze, że jest gejem (coming out jest zresztą ustalonym celem). Rozmowy o uczuciach i zwierzenia (również Piątki, która dzieli się swoimi życiowymi historiami i nierzadko dobiera się z bohaterami w swoiste duety wspólnych doświadczeń) stanowią punkt ciężkości Porad... i zdają się istotniejsze niż faktyczne zmiany wizerunku. Edukacyjność show wynikałaby zatem bardziej z równościowej tezy (ludzie są różni, ale wszyscy zasługują na szacunek i mają prawo do bycia wysłuchanymi), niż z trików i porad dotyczących stylów życia.

\section{Podsumowanie}

Choć proponowany przez pierwszą edycję programu wizerunek wykracza poza ideologię tradycyjnej męskości - włączając i eksponując takie cechy, jak otwartość, wrażliwość, czułość względem bliskich, umiejętność komunikowania swoich uczuć oraz opiekuńczość - to eksperci wciąż posługują się kategorią normy, do której należy aspirować. Chociaż postulowany model jest oczywiście bardziej włączający ${ }^{24}$, a eksperci wielokrotnie podkreślają, że trzeba być sobą (i, zwłaszcza w dalszych sezonach, warto łączyć kobiecość i męskość), to binarny podział jest wciąż widoczny i męskość pozostaje zbiorem (reprodukowanych) cech. Również tutaj jest ona swoiście przezroczysta i - wbrew opisanym powyżej kulturowym przemianom oraz reżimowi widzialności (wymuszającemu dbanie o siebie oraz traktowanie ciała jako bastionu męskości (Śmieja 2019, 9)) - wciąż nie traktuje się jej wprost jako

\footnotetext{
${ }^{23}$ Drugi sezon przyspiesza jeszcze bardziej. Efekt ten zostaje utrzymany również w kolejnych sezonach.

${ }^{24} \mathrm{~W}$ drugim sezonie włączony zostaje do niego transseksualny mężczyzna.
} 
roli czy zadania, w których można się ćwiczyć. Nie sposób jednak stwierdzić, na ile działanie to ma świadomy i celowy charakter - zbyt swobodne podejście do arsenału cech typowych mogłoby spowodować całościowe odrzucenie przesłania programu - a na ile wynika z ich naturalizacji i zinternalizowania. Jakkolwiek trudno nie zarzucić programowi naiwności ${ }^{25}$, skutecznie wpisuje się we wskazaną przez Brendę R. Weber rekontekstualizację męskości. Jak bardzo jest to temat drażliwy, dowodzi erupcja niechęci i nawoływania do bojkotu firmy Gillette (Hsu 2019; Topping, Lyons i Weaver 2019), będące efektem premiery nowej kampanii ${ }^{26}$. Reklama odwołuje się wprost do kategorii toksycznej męskości, zestawiając doniesienia medialne z fikcjonalnymi reprezentacjami działań bezpośrednio kojarzonych z tą kategorią (agresja, przemoc, przedmiotowe traktowanie kobiet), zachęca do sprzeciwiania się, aktywnego zapobiegania im i dawania dobrego przykładu nowym pokoleniom. Spot przywołuje dobrze znane zdanie: „boys will be boys” (chłopcy już tacy są) i parafrazuje je „because boys watching today, will be the man of tomorrow" (ponieważ chłopcy, którzy widzą to dzisiaj, będą mężczyznami przyszłości). Bardziej dosłowne i aktywizujące znaczenie zyskuje tym samym slogan marki „The Best Men Can Be”. Porady różowej brygady są refleksem rzeczywistości, w której konserwatywny, „tradycyjny porządek genderowy wydaje się szczególnie zagrożony" (Arcimowicz 2015, 34), czego efektem są retrotopie męskości oraz ruchy spod znaku Men’s Rights Movement. Promują jednocześnie i pozytywnie dowartościowują „nową męskość” - „partnerską, inkluzywną, pluralistyczną czy opiekuńczą” (Śmieja 2019, 5), stwarzając wrażenie, że właśnie taki wzorzec dominuje. Program tworzy zatem z jednej strony pozytywny model (podkreślający istotność męskiej bliskości i przyjaźni), którego domagał się choćby Ian Michael Black w swoim felietonie, a z drugiej zaś - w „dobie toksycznej męskości” - wydaje się udowadniać, że mężczyźni nie są tacy, jak ich stereotypowe reprezentacje.

\footnotetext{
${ }^{25}$ Program spotkał się również z zarzutem wsteczności - niewiele różniąc się od oryginału stacji Bravo. Jak zauważył Jude Dry: „usytuowanie pięciu cisseksualnych homoseksualnych mężczyzn jako wzorców queerowości w 2018 roku jest regresywne i redukcyjne”, środowisko LGBTQ jest bowiem dużo bardziej zróżnicowane (Dry 2018).

${ }^{26}$ Reklama zadebiutowała w mediach 14 stycznia 2019 roku.
} 


\section{Bibliografia}

Arcimowicz, Krzysztof. 2015. „Męskość w późnej nowoczesności”. [w:] Gender w sztuce / Gender in Art. Kraków: MOCAK.

Baragona, Louis. 2018. „Here's why we need the 'Queer Eye' reboot now more than ever". Insider. Dostęp: 27.01.2019. https://www.thisisinsider .com/queer-eye-reboot-netflix-review-2018-3.

Black, Michael Ian. 2018. „The Boys Are Not All Right”. The New York Times. Dostęp: 10.01.2019. https://www.nytimes.com/2018/02/21/opinion/ boys-violence-shootings-guns.html.

BUILD Series. 2018. „The New Fab Five Antoni Porowski, Bobby Berk, Karamo Brown, Jonathan Van Ness And Tan France Speak O”. Dostęp: 22.01.2019. https://www.youtube.com/watch?v=GHrykue7HiY.

Chan, Tim. 2018. „The Queer Eye Cast React to The Launch of Their New Book". Dostęp: 23.01.2019. https://variety.com/2018/tv/news/queer-eyebook-review-love-yourself-love-your-life-1203041851.

Dry, Jude. 2018. „Netflix’s ‘Queer Eye’ Reboot Doesn't Represent Queerness in 2018”. IndieWire. Dostęp: 24.01.2019. https://www.indiewire.com/ 2018/03/queer-eye-netflix-not-queer-1201932107.

Goad, Jim. 1998. The Redneck Manifesto. How Hillbillies, Hicks and White Trash Becames America's Scapegoats. New York-London-Toronto-Sydney: Simon and Schuster.

Godzic, Wiesław. 2004. Telewizja i jej gatunki: po „Wielkim Bracie”. Kraków: Universitas.

Hill, Annette. 2008. „Makeover Shows”. [w:] The Television Genre Book, red. Glen Creeber, 143-145. New York: Palgrave Macmillan.

Hsu, Tiffany. 2019. „Gillette Ad With a \#MeToo Edge Attracts Support and Outrage". The New York Times. Dostęp: 24.01.2019. https://www.ny times.com/2019/01/15/business/gillette-ad-men.html.

Hunt, Elle. 2017. „Behind the scenes of reality TV: 'You're a little bit daft to apply'”. The Guardian. Dostęp: 13.02.2020. https://www.theguardian .com/tv-and-radio/2017/jan/12/behind-the-scenes-of-reality-tv-you re-a-little-bit-daft-to-apply.

Jacyno, Małgorzata. 2007. Kultura indywidualizmu. Warszawa: Wydawnictwo Naukowe PWN.

Kimmel, Michael S. 2013. Angry white men. American masculinity at the end of an era. New York: Nation Books. E-book. 
Kimmel, Michael S. 2019. „Wściekli czy uzdrowieni? O współczesnych „retrotopiach męskości, zawiedzionym poczuciu uprzywilejowania, populizmie, pornografii i kobiecym gniewie. Z profesorem Michaelem Kimmelem rozmawia Wojciech Śmieja”. Czas Kultury 1, 7-13.

Kosofsky Sedgwick, Eve. 1992. Between Men. English Literature and Male Homosocial Desire. New York: Columbia University Press.

Krupers, Terry A. 2004. „Toxic Masculinity as a Barrier to Mental Health Treatment in Prison”. fournal of Clinical Psychology 6 (61), 713-724.

Levant, Ronald F. 1996. „A New Psychology of Men”. Professional Psychology: Research and Practice 3 (27). 259-265.

March for Our Lives. b.d. „Mission \& Story”. Dostęp: 14.03.2020. https:// marchforourlives.com/mission-story.

Pappas, Stephanie. 2019. „APA issues first-ever guidelines for practice with men and boys". Dostęp: 23.01.2019. https://www.apa.org/monitor/ 2019/01/ce-corner.aspx.

Popiel-Rzucidło, Ewa. 2015. „Telewizyjne metamorfozy a kultura ryzyka. Socjologiczny portret uczestniczek makeover show”. Media - KulturaKomunikacja Spoteczna 1(11), 85-99.

Salter, Anastasia i Bridget Blodgett. 2017. Toxic Geek Masculinity in Media: Sexism, Trolling, and Identity Policing. Cham: Palgrave Macmillan.

Schlichte, Garrett. 2018. „Netflix's Queer Eye Reboot Is an Antidote to Our Culture of Toxic Masculinity”. Harper's Bazaar. Dostęp: 23.01.2019. https://www.harpersbazaar.com/culture/film-tv/a18922990/queer-ey e-reboot-antidote-toxic-masculinity.

Śmieja, Wojciech. 2019. „Nikt nie rodzi się mężczyzną. Z Wojciechem Śmieją rozmawia Miłosz Markiewicz”. Fragile 3(45), 4-12.

Topping, Alexandra, Kate Lyons i Matthew Weaver. 2019. „Gillette \#MeToo razors ad on 'toxic masculinity' gets praise - and abuse”. Dostęp: 24.01.2019. https://www.theguardian.com/world/2019/jan/15/gillettemetoo-ad-on-toxic-masculinity-cuts-deep-with-mens-rights-activists.

Weber, Brenda R. 2006. „What Makes the Man? Television Makeovers, MadeOver Masculinity, and Male Body Image". International fournal of Men's Health 3(5), 287-306.

Wieczorkiewicz, Anna. 2013. Monstruarium. Gdańsk: słowo/obraz terytoria. E-book. 
Witt, Emily. 2018. „How the Survivors of Parkland Began the Never Again Movement”. The New Yorker. Dostęp: 14.03.2020. https://www.new yorker.com/news/news-desk/how-the-survivors-of-parkland-beganthe-never-again-movement.

Włodek, Patrycja. 2020. „Hipermęskość: skala kryzysu”. Ekrany 1, 34-38.

Wright, Jennifer. 2018. „Men Are Responsible for Mass Shootings”. Dostęp: 10.01.2019. https://www.harpersbazaar.com/culture/politics/a18207 60o/mass-shootings-male-entitlement-toxic-masculinity.

Wyrwińska, Dorota. 2020. Co się dzieje z mężczyznami? Analiza dyskursów dotyczacych kryzysu męskości $w$ artykułach prasowych oraz internetowych. Warszawa: Instytut Socjologii, Wydział Filozofii i Socjologii Uniwersytetu Warszawskiego. 


\title{
Abstract, keywords, about the author
}

\begin{abstract}
„Boys are not all right”. Queer Eye, America and toxic masculinity Article, which title quotes the one of Michael Ian Black's commentary published on The New York Times website ("The Boys Are Not All Right”, February 21, 2018), analyses Netflix's 2018 reboot of Queer Eye makeover show in context of toxic masculinity and mass shootings in American high schools.

The shooting in Stoneman Douglas High School in Parkland, Florida on February 14 was an 18th one in 2018 according to the Gun Violence Archive statistics. Commentators emphasised the fact that the perpetrators are mainly (white) man (teenage boys in case of school rampages) and connect it with toxic masculinity, a category that has been linked with Roland F. Levant research (published i.a. in his article The New Psychology of Men in 1996).

Rather optimistic views on Queer Eye usually concentrate on programme's promotion of tolerance towards sexual minorities or on - as the Fab 5 themselves state - acceptance. Stressing the genre convention (fixed and repeatable dramaturgy), ideology (homosexual man as a lifestyle expert) and ideological production choices (participants selection) I will analyse partaker's representation, pointing out the differences between real people and the dominant stereotypes in American culture they were chosen to dismantle, seeing it, if not as a broadening the concept of masculinity, then at least as a subtle cracks on the manhood monolith.
\end{abstract}

Keywords: Popular culture, Queer Eye, Television, Makeover show, Toxic masculinity

Monika Rawska graduated in Cultural Studies with a major in Film Studies. PhD candidate at The Faculty of Arts and Social Sciences at SWPS University in Warsaw. She has published several articles in monographs and journals (Panoptikum, Dialog, mała kultura wspótczesna), edited books (Exhibition Strategies of Selected Museums. Case Studies), journal issues (Kultura popularna) and anthologies ( $\mathrm{Pa}$ pierowi bandyci. Wypisy z polskojęzycznych powieści obiegu brukowego do 1939 roku [Paper bandits. Excerpts from Polish-language pulp fiction novels until 1939]; Filmowa Europa [Film Europe]). Her main fields of interest are popular culture, new genre cinema and representations of urban space in film.

https://orcid.org/oooo-ooo3-4310-8452

E-MAIL: mjrawska@gmail.com 